\title{
Heat Shock Protein Inhibitor
}

National Cancer Institute

\section{Source}

National Cancer Institute. Heat Shock Protein Inhibitor. NCI Thesaurus. Code C74526.

Any agent that inhibits functions of heat shock proteins (Hsp). Hsps are a group of homodimeric molecular chaperones that interact with a diverse group of proteins, assisting in their folding and in the elimination of any misfolded or damaged molecules. Although transiently expressed during cell cycle in normal cells, Hsps are constitutively elevated in various types of cancer which raises the apoptosis threshold of these tumor cells and provides protection against cytotoxic agents. Hsp inhibitors may destabilize, and facilitate deg radation of proto-oncoproteins leading to reversal of apoptosis regulation and cell death. 